\title{
Piezosebészeti eszköz és a sagittalis csontfürész intraossealis hőtermelésének in vitro összehasonlító vizsgálata
}

\author{
DR. CZIRIÁK NORBERT BENCE*, DR. SZALMA JÓZSEF**, DR. VÁG JÁNOS***, DR. BOGDÁN SÁNDOR ${ }^{* * * *}$
}

\begin{abstract}
Vizsgálatunkban in vitro körülmények között összehasonlítottuk a piezosebészeti eszköz és a sagittális csontfürész által termelt hőmennyiséget.

Sertésbordába K-típusú hőérzékelőt rögzítettünk, amitől $1 \mathrm{~mm}$ távolságra, „legyezőszerü” folyamatos mozgással 30 30 bordát vágtunk át sagittalis fürésszel (S-8 S - Elcomed, W\&H) és piezosebészeti eszközzel (B6 - Piezomed, W\&H). Utóbbival hútési ciklusokat közbeiktatva 30 mintán szakaszos vágást is végeztünk.

Sagittalis fürésszel végzett osteotomia során nem mértünk $47^{\circ} \mathrm{C}$ feletti értéket. Piezoelektromos eszközzel „legyezőszerú”, folyamatos mozgással végzett vágás mellett a mérési eredmények $16,2 \pm 3,53 \%$-a elérte a kritikus hőmérsékletértéket, hútési ciklusok közbeiktatásával ez az érték 2,6 $\pm 0,96 \%$-ra csökkent $(p<0.001)$. A hőmérséklet egyetlen esetben sem haladta meg a $47^{\circ} \mathrm{C}$-ot több mint 20 másodpercig.

A piezosebészeti eszköz biztonságosan használható, azonban az osteonecrosis kialakulásának esélyét tovább csökkenthetjük hütési ciklusok közbeiktatásával, intermittáló műszerhasználattal és maximális vízhűtéssel.
\end{abstract}

Kulcsszavak: osteotomia, osteonecrosis, piezosebészeti eszköz, sagittalis csontfürész

\section{Bevezetés}

Az arc-, állcsont- és szájsebészeti beavatkozások (dygnathiák mútéte, daganatok miatti resectiók, csontpótlások stb.) során számos esetben kerül sor az állcsontok teljes, vagy részleges átvágására (osteotomia). Régebben főként forgó eszközökkel történt a csontok megmunkálása, a közelmúltban emellett olyan új, modern eszközök is megjelentek, mint a sagittalis fürészek és a piezosebészeti eszközök.

Utóbbiak legnagyobb előnye a szelektív csontvágási képesség, amellyel elkerülhetjük az ér- és idegsérüléseket, lágyrész-sérüléseket [15]. A készülék ultrasonicus rezgése a hútőfolyadékból buborékokat formál, majd az osteotomia helyére „berobbanva” tisztítja, vérteleníti a mútéti területet (kavitációs effektus), illetve egyes baktérium speciesek sejtfalának feltöredezése révén antibakteriális hatást fejt ki $[2,12]$. A sebgyógyulás korai fázisa gyorsabban lezajlik [14], a kis erővel alkalmazott múszerhasználat pedig precízebb vágást, jobb taktilis érzékelést biztosít. Számos előnye mellett hátrányaként a szignifikánsan megnövekedett mütéti idő említhető [8]. A szakirodalomban megoszlanak a vélemények a vágás közben keletkező hőmennyiséget illetően, egyes források csökkent [11], míg mások fokozott hőtermelődést tapasztaltak piezo-asszisztált mútét esetén [10]. A nemzetközi irodalomban tényként kezelt közlemény szerint [5] a kritikusnak tartott $47^{\circ} \mathrm{C}$ feletti hőmérsékleten átlagosan 1 perc után a csontot irreverzibilis hőkárosodás éri, ami végül osteonecrosishoz vezet. Magasabb hőmérséklet $\left(90^{\circ} \mathrm{C}\right)$ már néhány másodperc alatt is csontelhalást okoz [6], ami rendkívül kedvezőtlenül befolyásolja az átültetett csontok beépülését és a donor-, illetve recipiens helyek gyógyulását is. Célunk a piezosebészeti eszközzel és sagittalis fürésszel végzett osteotomia során képződő hőmenynyiség mérése és összehasonlítása, illetve gyakorlati ajánlások megfogalmazása a klinikusok számára a hő okozta osteonecrosis szövődményeinek elkerülése érdekében.

\section{Anyag és módszer}

A mérésekhez friss sertésbordát (átlagos vastagság: $2,0 \pm 0,29 \mathrm{~cm}$ ) használtunk. A bordákat $1,1 \mathrm{~mm}$ átmérőjú fúróval (L44.5 / $12 \mathrm{~mm}$ Synthes $\mathrm{GmbH}$, Oberdorf, Svájc) perforáltuk, majd termosztátban $37^{\circ} \mathrm{C}$-ra melegítettük. A csontot satuba fogtuk, majd az előfúrt lyukba hővezető pasztával K-típusú hőelemet (érzékelő) rögzítettünk, amit digitális thermometerhez csatlakoztattunk (EL-EnviroPad-TC, Lascar Electronics Ltd., Salisbury, Egyesült Királyság) (1. ábra). A készülék másodper- 


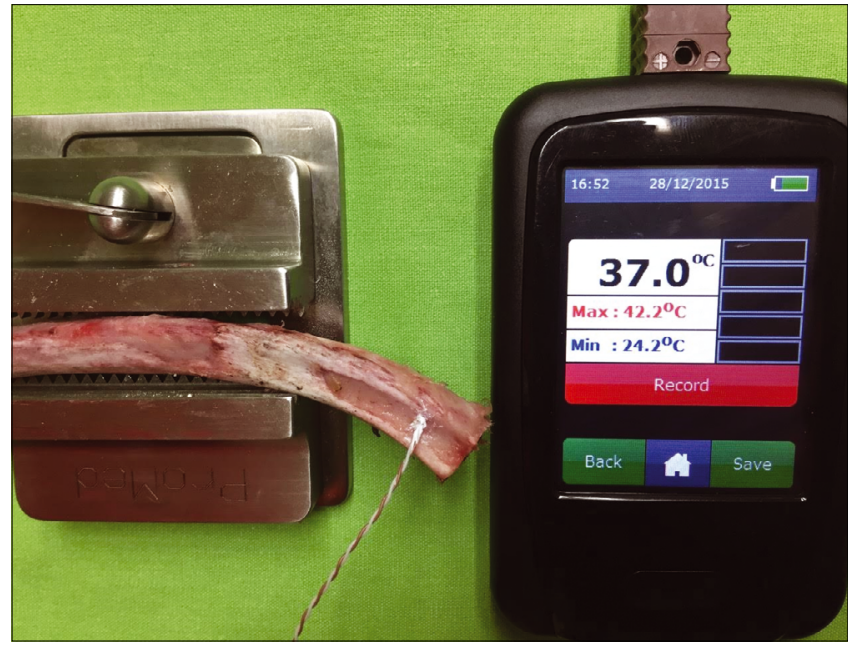

1. ábra: A thermometerhez csatlakoztatott K-típusú hőérzékelő a csontba helyezve

cenként rögzítette a vágások során a csont hőmérsékletét.

Valamennyi borda osteotomiáját ugyanaz a személy végezte el a hőelemtől $1 \mathrm{~mm}$ távolságra (2. ábra). A vágásokhoz kétféle eszközt használtunk: Piezomed piezosebészeti eszközt, B6 típusú végződéssel (W\&H Dentalwerk, Bürmoos $\mathrm{GmbH}$, Ausztria), illetve S-8 S típusú sagittalis mozgást végző csontfürészt Elcomed sebészi motorhoz csatlakoztatva (W\&H Dentalwerk, Bürmoos $\mathrm{GmbH}$, Ausztria) (3. ábra).

Vizsgálatunk során három módszert alkalmaztunk a csontok osteotomiájához:

Piezomed I: Folyamatos mozgatással 30 borda átvágása történt.

Piezomed II: Szakaszos múszerhasználattal 30 osteotomiát végeztünk (váltogatva 8 másodpercig folyamatos mozgatással vágtunk, majd a csontból kiemelve a végződést 4 másodperces hútési ciklusokat iktattunk közbe).

Csontfürész: Folyamatos műszerhasználattal 30 bordát vágtunk át.

Minden esetben az alaptechnika a „legyezőszerü” mozgatás volt (a borda hossztengelyére merőlegesen, a vágás két végpontja között történő, állandó sebességü, oda-vissza irányuló mozgás).

A gyártó utasítása szerint a készülékek optimális használatához rendszeres hűtési szakaszokat kell közbeiktatni, illetve állandóan mozgatni kell az aktív végződéseket. Ezáltal csökkenthető a mútéti területen keletkező hő mennyisége. Ez a típusú mozgás a mütét során külön odafigyelést igényel a klinikustól . Amenynyiben helytelenül, „legyezőszerü” mozgatás nélkül (folyamatos nyomás mellett ugyancsak vízhütéssel) használjuk a készüléket, feltételezésünk szerint nagyobb hőképződéssel kell számolnunk. Ennek modellezésére további 5-5 bordát vágtunk át piezosebészeti eszköz-

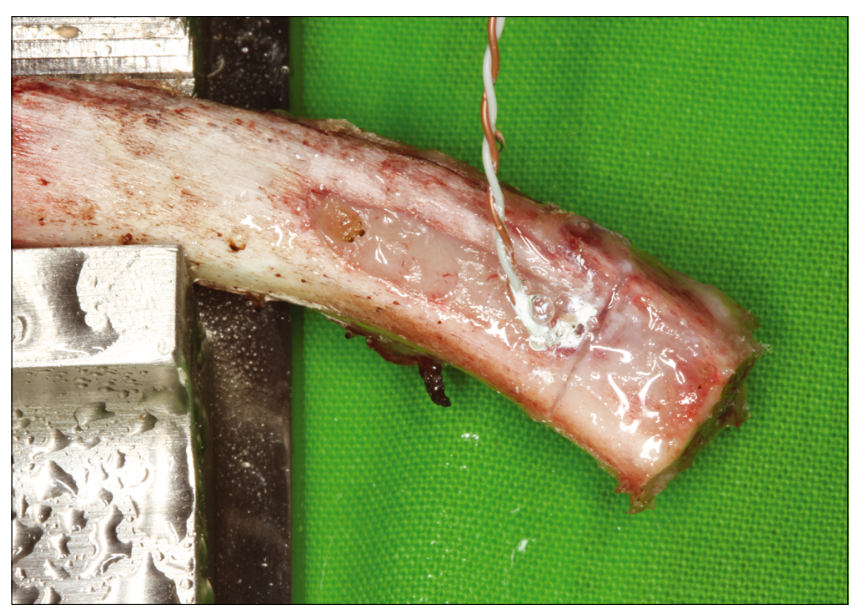

2. ábra: A hőérzékelőtől $1 \mathrm{~mm}$ távolságra végzett osteotomia

zel és sagittalis csontfürésszel a helytelen múszerhasználat modellezésére. Minden egyes csontvágás során $21^{\circ} \mathrm{C}$-os sóoldattal, a készüléken beállítható maximális vízhútést alkalmaztuk.

A különböző technikákat háromféle módon hasonlítottuk össze. Kiszámítottuk, hogy a teljes átvágás során

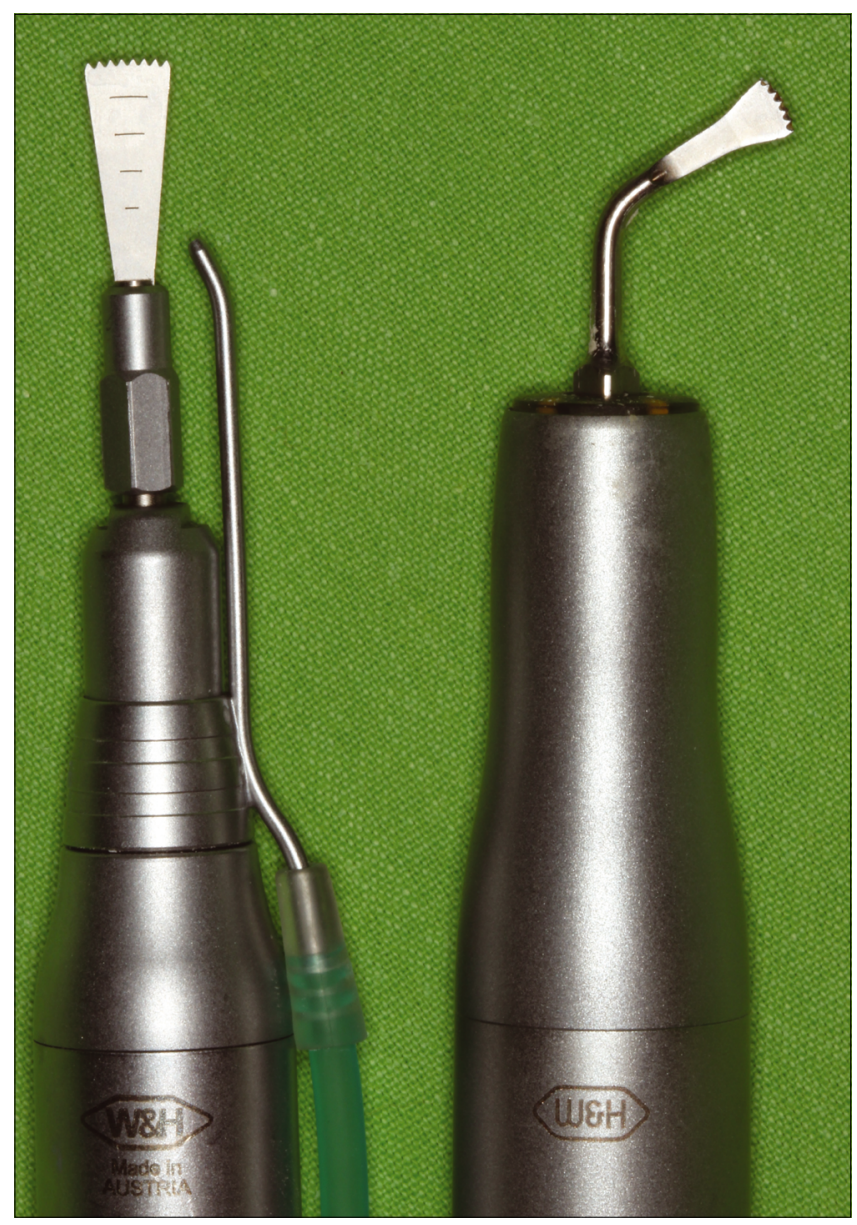

3. ábra: S-8 S sagittalis csontfürész

Elcomed sebészi motorral múködtetve (bal oldalon);

Piezomed készülékhez csatlakozatott B6 típusú végződés (jobb oldalon) 


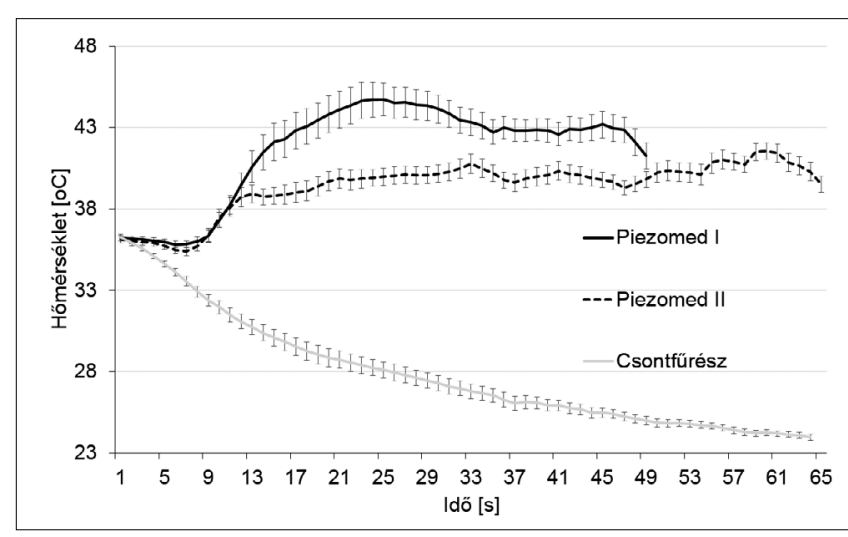

4. ábra: A csontok átvágása során mért átlaghőmérsékletek az idő függvényében

összesen hány másodpercig lépte át a csontban mért hőmérséklet a kritikus $47^{\circ} \mathrm{C}$-ot. A hőmérsékleti regisztrációs görbe alatti területtel jellemeztük a teljes mútét alatt leadott hőmennyiséget és a csont átvágásához szükséges időt is rögzítettük.

Az adatok a szövegben és az ábrákon átlag \pm standard hiba formában tüntettük fel. Az eredményeket Microsoft Excel programban értékeltük, a statisztikai kiértékeléshez a „linear mixed modelt” alkalmaztuk. Post-hoc páros összehasonlításnál Bonferroni korrekciót végeztünk és szignifikáns különbségnek a $p<0,05$ értéket tekintettük. A kiértékelés a Statistica V12 programmal (StatSoft Inc., Tulsa, OK, USA) történt.

\section{Eredmények}

A $37^{\circ} \mathrm{C}$-ra előmelegített bordáknak a vágás megkezdésének pillanatában mért kiindulási hőmérsékletértékei a 1. táblázatban láthatók.

Piezoelektromos eszközzel a csont felszínén végzett vágás során megfelelő hútést lehet elérni, amit bizonyít a Piezomed I-II módszert ábrázoló függvény együttes hőmérsékletcsökkenése az első 8 másodpercben (4. ábra). Mélyebb csontállományban végzett osteotomia során viszont ugrásszerű hőmérsékletemelkedést észleltünk. A Piezomed II esetén ez megszúnt a hütési ciklusok közbeiktatásával, a továbbiakban látható „fürészfogszerư" rajzolat pedig a 8 másodperces vágási és 4 másodperces hútési fázisok váltakozását repre-

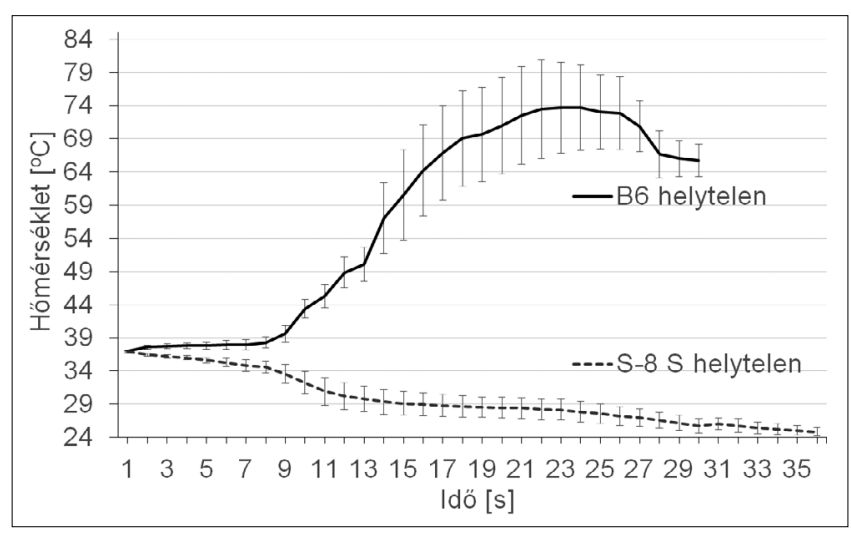

5. ábra: „Legyezőszerư” mozgás nélkül

(helytelen müszerhasználattal) végzett csontvágások átlaghőmérsékletei

zentálja. A csontfürésszel végzett vágás hőtermelését ábrázoló függvény folyamatosan csökkenő tendenciát mutatott, a görbe legmagasabb pontja a kiindulási hőmérsékletérték volt. Helytelen múszerhasználattal is hasonló lefutású görbét kaptunk sagittalis csontfürész esetén, ellenben piezoelektromos eszközzel már a csont felszínén végzett vágás során is lassú, míg mélyebb csontállományban meredek hőmérséklet emelkedést figyeltünk meg (5. ábra).

A csontok átvágása Piezomed I módszerrel szignifikánsan kevesebb időt vett igénybe, mint Piezomed II esetén $(49,0 \pm 1,74 s$ vs. $57,8 \pm 1,74 s, p<0,01)$ és gyorsabb volt, mint a csontfürész $(63,8 \pm 2,51 \mathrm{~s}, \mathrm{p}<$ 0,001 ) (6. ábra). A helytelen műszerhasználattal végzett kísérletünk során is átvágtuk a csontokat, de nem teljes keresztmetszetükben. Ez piezosebészeti eszköz esetén $31,2 \pm 1,82$ másodpercet, míg sagittalis csontfürésszel 38,6 $\pm 2,24$ másodpercet vett igénybe.

Az egyes mérések során kapott adatokból látszik, hogy Piezomed I esetén magasabbra emelkedett a hőmérséklet, mint a hütési ciklusok közbeiktatásával végzett Piezomed II módszerrel (1. táblázat). Piezomed I technikával a csont szignifikánsan hosszabb ideig volt $47^{\circ} \mathrm{C}$ feletti hőmérsékletnek kitéve, mint a Piezomed II csoportban. Csontfürész esetén még helytelen használat mellett is hőmérséklet-csökkenést mértünk, míg piezoelektromos eszközzel $90,3^{\circ} \mathrm{C}$-ig is emelkedett a hömérséklet.

Piezomed I csoportban átlagosan az osteotomia teljes idejének 16,2 $\pm 3,53 \%$-ban emelkedett a hőmérsék-

1. táblázat

A különböző csontpreparáló eljárásokkal végzett osteotomiák hatása a mért paraméterekre (SE értékek feltüntetve)

\begin{tabular}{|l|c|c|c|c|c|}
\hline & Piezomed I & Piezomed II & Csontfürész & B6 helytelen & S-8 S helytelen \\
\hline Kiindulási hőmérséklet & $36,2 \pm 0,03^{\circ} \mathrm{C}$ & $36,1 \pm 0,03^{\circ} \mathrm{C}$ & $36,2 \pm 0,04^{\circ} \mathrm{C}$ & $37,0 \pm 0,04^{\circ} \mathrm{C}$ & $36,9 \pm 0,06^{\circ} \mathrm{C}$ \\
\hline Átlaghőmérséklet & $41,5 \pm 0,11^{\circ} \mathrm{C}$ & $39,0 \pm 0,06^{\circ} \mathrm{C}$ & $27,7 \pm 0,06^{\circ} \mathrm{C}$ & $57,4 \pm 1,30^{\circ} \mathrm{C}$ & $29,2 \pm 0,41^{\circ} \mathrm{C}$ \\
\hline Maximum hőmérséklet & $55,0^{\circ} \mathrm{C}$ & $51,2^{\circ} \mathrm{C}$ & $36,9^{\circ} \mathrm{C}$ & $90,3^{\circ} \mathrm{C}$ & $37,3^{\circ} \mathrm{C}$ \\
\hline Leghosszabb $47^{\circ} \mathrm{C}$ feletti időintervallum & $20 \mathrm{seC}$ & $5 \mathrm{seC}$ & $0 \mathrm{sec}$ & $23 \mathrm{seC}$ & $0 \mathrm{seC}$ \\
\hline
\end{tabular}


let $47^{\circ} \mathrm{C}$ fölé, ugyanakkor a Piezomed II csoportban ez az érték 2,6 \pm 0,96\%-ra csökkent ( $p<0,001,7$. ábra). A piezosebészeti eszköz helytelen használata esetén a hőmérséklet szignifikánsan többször lépte át a $47^{\circ} \mathrm{C}$ ot $(61,9 \pm 2,36 \%, p<0,001)$ a gyártó által ajánlott szakaszos vágáshoz viszonyítva. A sagittalis csontfürész használatakor egyik csoportban sem mértünk kritikus hőmérsékletértéket.

Az osteotomiák során a legnagyobb mennyiségű hőterhelés (görbe alatti terület) a Piezomed II módszerrel érte a csontszövetet (8. ábra), de nem mutatott szignifikáns különbséget a Piezomed I csoporthoz és a csontfürészhez képest.

\section{Megbeszélés}

Az osteotomia során keletkező hőmennyiséget számos tényező befolyásolja. Vizsgálatunk során főként a műszerhasználatot, a hútés mechanizmusát és a vágási mélységet modelleztük. Ezenfelül a csontra kifejtett nyomás, a hűtőfolyadék hőmérséklete, az alkalmazott fordulatszám, a corticalis-spongiosa arány, illetve a végződés mérete, geometriája és anyaga is hatással van a hőfejlődésre [3].

A piezosebészeti eszköz alkalmazásánál a gyártó utasításainak betartása mellett külön figyelmet kell fordítani a csont hútésére, amely mélyebb csontállományban elégtelen lehet. Piezomed II esetén több ideig tartott a bordák teljes átvágása, így ugyan összességében több hő érte a csontot, de ez sokkal ritkábban lépte át a kritikus értéket, mint a Piezomed I módszernél. Ezért eredményeink alapján javasoljuk a hútési szakaszok közbeiktatását, amivel csökkenthetjük a hőmérséklet kiugrásokat.

A helytelen müszerhasználat során kapott görbék különböző lefutására részben magyarázatot ad a hútés eltérő mechanizmusa. Piezoelektromos eszköz esetén az ultrasonicus rezgés által porlasztott hütőfolyadék éri a csontfelszínt, míg sagittalis fürésznél folyamatos vízsugár. A csontfürésszel végzett osteotomia az előmelegített borda lehúlését okozta, ami adódhat a folyamatos vízsugár nagyobb hútőkapacitásából, illetve a sagittalis mozgás miatt még helytelen használat mellett is mélyebb rétegekbe tud penetrálni a hútővíz, így a $47^{\circ} \mathrm{C}$-os kritikus hőmérsékletértéket meg sem közelítettük az osteotomiák alatt. Piezoelektromos eszköz esetén viszont akadályozott a fiziológiás sóoldat behatolása a csontállományba, ahol méréseinkben $90,3^{\circ} \mathrm{C}$ ra is emelkedett a hömérséklet. $A$ következmény másodperceken belül kialakuló osteonecrosis lehet, amely rendkívül kedvezőtlenül befolyásolja kezelésünk sikerességét. A mérések rámutatnak, hogy milyen fontos az ultrasonicus végződést állandóan mozgatni a vágások során. Sagittalis csontfürésszel vízhűtés mellett a necrosis veszélye nem áll fenn, míg piezoelektromos eszköz esetében kellő körültekintés hiányában nagyon könnyen a csont felhevülését, elhalását idézhetjük elő. Ezért a hőkárosodás következményeinek kiküszöbölé-

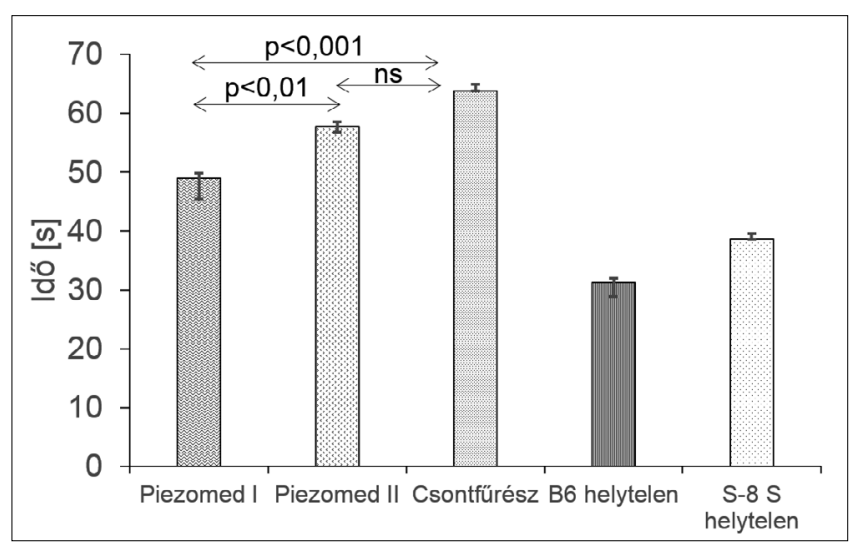

6. ábra: A különböző csontpreparáló eljárásokkal végzett osteotomiák teljes vágási idejének összehasonlítása. $A z$ ábrán az átlag \pm SE feltüntetve

(ns: nem szignifikáns, p: szignifikáns különbség két csoport között).

sére érdemes szigorúan betartani az ajánlásokat a piezoelektromos eszközzel végzett mútétek során.

Osteotomia során intermittáló, azaz szakaszos múszerhasználat ajánlott $[9,13]$. A rövid megszakítások alatt a hútőfolyadék jobban eléri a megmunkált csontfel-

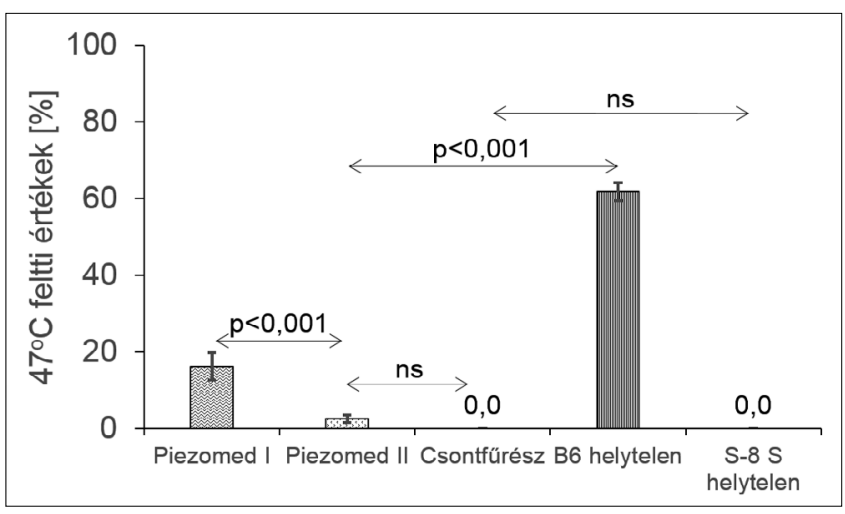

7. ábra: $47^{\circ} \mathrm{C}$ feletti értékek elődfordulási gyakorisága a teljes vágási idő során. Az ábrán az átlag \pm SE feltüntetve (ns: nem szignifikáns, p: szignifikáns különbség két csoport között).

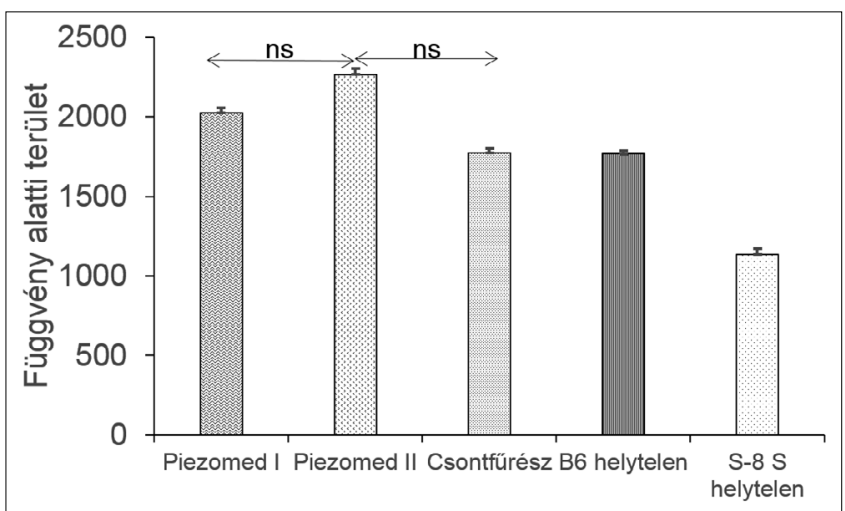

8. ábra: A különböző csontpreparáló eljárásokkal végzett osteotomiák során létrejött teljes hőterhelés. Az ábrán az átlag \pm SE feltüntetve

(ns: nem szignifikáns, p: szignifikáns különbség két csoport között). 
színt, így nagyobb hőmérsékletcsökkenést eredményez, aminek mélyebb rétegekben fokozottabb jelentősége van. Szakaszos vágás során a vizsgált paraméterek mindegyikénél szignifikánsan alacsonyabb hőképződést tapasztaltunk a folyamatos vágáshoz viszonyítva, ami alátámasztja az irodalomban ajánlottakat.

A piezosebészeti eszközöket körülbelül 500 gramm nyomással ajánlott használni [16], míg hagyományos fúróknál és csontfürészeknél mindenképpen nagyobb (2-3 kg) nyomást kell kifejteni a hatékony vágáshoz, fúráshoz [9]. A nyomás fokozásának nemkívánatos hatása a piezoelektromos eszköz aktív végződésének korlátozott mozgathatósága, ami a precizitást csökkenti, ezenfelül a rezgésre fordított energia is hővé disszipálódik, ami szignifikánsan megemeli a képződő hő mennyiségét [9].

A készüléken beállítható maximális vízhűtéssel végezzünk osteotomiát, mert nagyobb mennyiségű fiziológiás sóoldattal hatásosabban megelőzhetjük a csont helyi túlmelegedését. Tovább csökkenthetjük az osteonecrosis kialakulásának lehetőségét, ha alacsonyabb hőmérsékletű hütőfolyadékot (akár $4^{\circ} \mathrm{C}$-ra lehűtve) alkalmazunk a mütét során [4].

Egyes készülékeken létezik olyan funkció, amellyel csökkenthető a helytelen használatból eredő káros hőmérséklet-emelkedés. Ebben az esetben a készülék a nyomás növelésével fordítottan arányosan szabályozza a teljesítményt, így érdemes osteotomia során ezt a funkciót alkalmazni.

Hosszú ideig végzett csontvágásoknál a kézidarab felmelegedése tapasztalható, ezért néhány percenként érdemes rövid szünetet közbeiktatni, különben a hő átadódik az aktív végződésnek is [4]. A piezoelektromos eszközök belső hűtéssel működnek, így az átáramló fiziológiás sóoldat hőmérsékletét is emeli.

Bár a piezotechnika a sagittalis fürészhez képest lényegesen nagyobb hőtermelődéssel jár, a kritikusnak tartott $47^{\circ} \mathrm{C}$-os határt 1 percig meghaladó értékeket nem mértünk, így az ajánlások szigorú betartásával biztonságosan kihasználhatjuk a piezoelektromos eszközök nyújtotta számos előnyt.

\section{Köszönetnyilvánítás}

Szeretnénk köszönetet mondani Fejérváry Gábornak a W\&H magyarországi képviselete vezetőjének a vizsgálatokhoz nyújtott önzetlen segítségéért és a rendelkezésünkre bocsátott eszközökért.

\section{Irodalom}

1. Aldabagh AH: The significance of motor speed on heat generation during implant drilling (experimental study on bovine bone). Al-Rafidain Dent. J 9 2009; 303-306.

2. Blus C, Szmukler-Moncler S: Atraumatic tooth extraction and immediate implant placement with Piezosurgery: evalua-tion of 40 sites after at least 1 year of loading. Int J Periodontics Restorative Dent 2010; 30: 355-363.

3. Bogovič V, Svete A, Rupnik K, Bajsić I: Experimental analysis of the temperature rise during the simulation of an implant drilling process using experimental designs. Measurement 632015 ; 221-231.

4. Eggers G, Klein J, Blank J, Hassfeld S: Piezosurgery: an ultrasound device for cutting bone and its use and limitations in maxillofacial surgery. Br J Oral Maxillofac Surg. 2004; 42: 451453.

5. ERIKSson RA, Albrektsson T: The effect of heat on bone regeneration: an experimental study in the rabbit using the bone growth chamber. J Oral Maxillofac Surg 1984; 42(11): 705-711.

6. Gehrke SA, Pazetto MK, de Oliveira S, Corbella S, Taschieri S, MARDEGAN FE: Study of temperature variation in cortical bone during osteotomies with trephine drills. Clin Oral Invest 2014; 18: 1749-1755.

7. KALIDINDI V: Optimization of drill design and coolant systems during dental implant surgery M.Sc. thesis, University of Kentucky, 2004.

8. Labanca M, Azzola F, Vinci R, Rodella L: Piezoelectric surgery: twenty years of use. Br J Oral MaxillofacSurg 2008; 46: 265269.

9. Pavlíková G, Foltán R, Horká M, Hanzelka T, Borunská H, Šed̂́ $\mathrm{J}$ : Piezosurgery in oral and maxillofacial surgery. Int J Oral Maxillofac Surg 2011; 40: 451-457.

10. Rashad A, Kaiser A, Prochnow N, Schmitz I, Hoffmann E, MaurER P: Heat production during different ultrasonic and conventional osteotomy preparations for dental implants. Clin Oral Implants Res 2011; 22: 1361-1365.

11. Rashad A, Sadr-Eshkevari $P$, Heiland $M$, Smeets R, Hanken $H$, GRÖBE $A$, et al: Intraosseous heat generation during sonic, ultrasonic and conventional osteotomy. J Craniomaxillofac Surg 2015; 43: 1072-1077.

12. Schlee M, Steigmann M, Bratu E, Garg AK: Piezosurgery: basics and possibilities. Implant Dent 2006; 15: 334-340.

13. Schütz S, Egger J, KüHL S, FILIPPI A, LAMBrecht JT: Intraosseous temperature changes during the use of piezosurgical inserts in vitro. Int J Oral Maxillofac Surg 2012; 41: 1338-1343.

14. Tsai SJ, Chen YL, Chang HH, Shyu YC, Lin CP: Effect of piezoelectric instruments on healing propensity of alveolar sockets following mandibular third molar extraction. J Dent Sci 2012; 7(3): 296-300.

15. Vercellotti T, Paoli SD, Nevins M: The Piezoelectric Bony Window Osteotomy and Sinus Membrane Elevation: Introduction of a New Technique for Simplification of the Sinus Augmentation Procedure. Int J Perio Rest Dent 2001; 21: 561-567.

16. Vercelotti T: Technological characteristics and clinical indications of piezoelectric bone surgery. Minerva Stomatol 2004; 53: 207-214. 


\section{CZIriák NB, Szalma J, VÁG J, Bogdán S}

\section{In vitro comparison of the effect of piezosurgery and conventional bone preparation technique on intraosseous heat generation}

The aim of this in vitro study was to compare the effect of sagittal saw handpiece with a piezoelectric device on the rise in intraosseous temperature and on the preparation time.

100 native pieces of pork ribs were cut either with S-8 S handpiece connected to Elcomed surgical motor $($ W\&H) $(n=30)$ or with B6 insert connected to Piezomed $(W \& H)$ using continuous movement $(n=30)$ or with B6 using short breaks to perform intermittent cutting $(n=30)$. The rest were cut either by $S-8 S(n=5)$ or by $B 6(n=5)$ both applied by permanent pressure. The intraosseous temperature was measured by K-type thermocouple connected to digital thermometer placed in the bone $1 \mathrm{~mm}$ away of the cutting line. The heat generated and the time of the complete cutting were recorded.

In S-8 S group the temperature never rose above $47^{\circ} \mathrm{C}$. Using the $\mathrm{B} 6$ with permanent movement the critical temperature was reached in $16.2 \pm 3.53 \%$ of the cases while taking breaks decreased the results to $2.6 \pm 0.96 \%$ ( $p<$ $0.001)$. In no cases the temperature elevation above $47^{\circ} \mathrm{C}$ lasted more than $60 \mathrm{sec}$. Applying the B6 by permanent pressure resulted in heat up to $90.3^{\circ} \mathrm{C}$.

Our results suggest that piezoelectric device could use safely according to the factory instructions, however further reduce of heat load could be achieved if the intermittent cutting motion combined with short-time cooling periods.

Key words: osteotomy, osteonecrosis, piezosurgery, saw handpiece, thermocouple 